
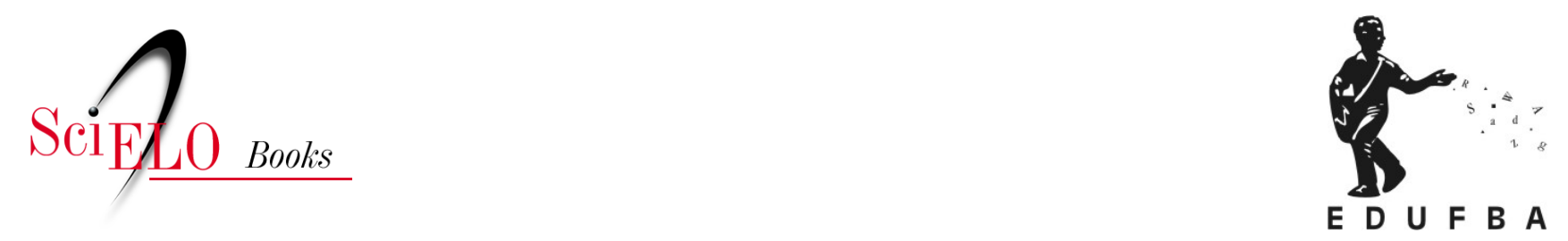

\title{
Capítulo 6 \\ Posição promotora de campos afetivos hipergeneralizados: a manutenção da maternidade como possibilidade futura
}

\author{
Vívian Volkmer Pontes
}

\section{SciELO Books / SciELO Livros / SciELO Libros}

PONTES, V.V. Posição promotora de campos afetivos hipergeneralizados: a manutenção da maternidade como possibilidade futura. In: Trajetórias interrompidas: perdas gestacionais, luto e reparação [online]. Salvador: EDUFBA, 2016, pp. 164-185. ISBN: 978-85-232-2009-9.

https://doi.org/10.7476/9788523220099.0008.

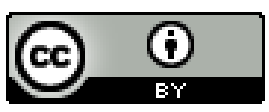

All the contents of this work, except where otherwise noted, is licensed under a Creative Commons Attribution 4.0 International license.

Todo o conteúdo deste trabalho, exceto quando houver ressalva, é publicado sob a licença Creative Commons Atribição $\underline{4.0}$. 
CAPÍTULO 6

Posição promotora de campos afetivos hipergeneralizados: a manutenção da maternidade como possibilidade futura 


\title{
Narrativa autobiográfica da trajetória reprodutiva de Eduarda no contexto privado de saúde
}

\author{
O sonho acaba... de repente tudo \\ acaba (Eduarda).
}

Eduarda possui trajetória reprodutiva marcada por sete gestações e seis abortos espontâneos - ocorridos no período de cinco a nove semanas de gestação. No momento em que foi realizada a entrevista encontrava-se grávida de cinco semanas. Em sua narrativa relata que a primeira gravidez havia sido planejada pelo casal para acontecer quando estivessem com três anos de casados, a fim de que pudessem "curtir a vida a dois antes de aumentar a familia". E assim, quando estavam com três anos de casados, resolveram dar início às tentativas de gestação, após a realização de alguns exames médicos para atestar a saúde reprodutiva do casal. Com os resultados dos exames favoráveis à concepção, concluíram ter chegado o momento propício para ter um filho: "Sempre tinha aquela expectativa de que tudo ia fluir, de que tudo ia dar certo". Para Eduarda, um filho viria para "somar", para "completar a família".

A primeira gestação não tardou a acontecer, seis meses depois da suspensão do contraceptivo constatou que estava grávida. Porém, a gestação foi precocemente interrompida nas sete primeiras semanas. Eduarda relata que a médica que a acompanhava lhe havia explicado que a gestação poderia não evoluir devido a um cisto que possuía em um dos ovários. O aborto espontâneo foi diagnosticado em um exame de ultrassonografia de rotina, parte do acompanhamento pré-natal que realizava. Na medida 
em que o aborto ficou retido, precisou ser submetida ao procedimento médico da curetagem uterina:

Foi muito difícil, tanto que a gente, ninguém esperava, eu 'tava' sozinha no dia, a gente não esperava. Aí pronto, teve que fazer a remoção do cisto, eu tive que me internar, porque eu não perdi com sangramento, aí pronto.

Após o enfrentamento dessa difícil situação, permeada por muito sofrimento, o casal voltou a engravidar novamente. Seguindo a orientação médica para que aguardasse seis meses antes de uma nova tentativa de gravidez, o casal estava confiante em relação à próxima gestação: “ $a$ gente nunca pensou: 'ah, será que vai perder de novo?', não". Contraditoriamente, Eduarda relata que durante o primeiro exame de ultrassonografia não se sentiu muito bem, e acredita que isto ocorreu devido ao receio de que uma nova perda voltasse a acontecer: "Eu 'tava' acho que um pouco de receio, de passar pelo que tinha passado primeiro, acho que eu 'tava' com um pouco de receio... Na verdade os meus ultrassons sempre foram muito difíceis por causa desse histórico". Por este motivo, solicitou a companhia do marido. O exame realizado revelaria a ocorrência de mais um aborto espontâneo marcado mais uma vez por muito sofrimento, por procedimentos médicos para a retirada do aborto retido e pela necessidade do internamento hospitalar:

Quando fez o ultrassom tinha perdido de novo, o neném já não 'tava', já não tinha mais batimentos cardíacos, aí dessa vez não deu nem tempo de ver o bebê com batimentos cardíacos, entendeu, ver direitinho, aí pronto, aí, tivemos que nos internar de novo... aí foi todo aquele procedimento, fazer curetagem, não sei o que, aí chorava, 'né', sentia...

Durante esse período, Eduarda e o marido contaram com uma ampla e importante rede de apoio composta por familiares, amigos e irmãos da igreja evangélica que frequentavam e isto os ajudou a "superar" as difíceis circunstâncias. Além disso, Eduarda relata ter buscado apoio de Deus, através da oração, "refugiando-se em seu colo" e estabelecendo com Ele um diálogo: 
Eu pedi a Deus que tranquilizasse o meu coração pra eu viver o tempo dele e se eu tivesse que esperar, que ele iria me dar forças pra esperar, que as coisas nem sempre acontecem como a gente quer, 'né', e a gente tem que estar aberto para isso, 'né', então isso aí me ajudou muito...

Novamente aguardaram o tempo recomendado pelos médicos para voltar a engravidar, mas desta vez, a gestação "demoraria" cerca de três anos para acontecer. Eduarda acredita que, nos primeiros meses, o elevado nível de ansiedade experienciado por ela e relacionado à vontade de engravidar o mais breve possível consistiu, até certo ponto, no motivo para a sua dificuldade para engravidar:

Pelo sentido de querer estar grávida, pelo desejo de querer estar grávida, aí, ficava contando todo dia, 'né', qual dia eu 'tava' no ciclo, se um dia a menstruação atrasasse eu já queria fazer o exame, e ficava procurando, é, sintomas, entendeu, de gravidez, e isso realmente atrapalhou muito. Eu reconheço que no primeiro ano, por volta de um ano e meio, foi realmente ansiedade que atrapalhou de acontecer uma nova gravidez.

Com o foco principal da sua vida direcionado para o objetivo de engravidar, Eduarda acredita ter até mesmo experienciado uma gestação de cunho psicológico, na medida em que sentiu alguns sintomas de gravidez, como enjoos, apesar de não estar grávida. A partir desses acontecimentos e de uma autorreflexão sobre eles, Eduarda tomou a decisão de tentar reduzir o nível de ansiedade experienciado, tentando mudar, temporariamente, o foco da maternidade para outras atividades: "quando eu vi que essas coisas estavam acontecendo, eu falei assim: 'Não, eu não posso permitir que isso aconteça, eu tenho que mudar, eu tenho que me tranquilizar, tenho que... tirar um pouquinho isso do foco". Assim, procurou envolver-se em outras atividades na igreja que frequentava, no trabalho, e em casa. Também recorreu a Deus, através de suas orações: "fui buscando isso diante de Deus, 'né', essa tranquilidade, essa paz, de estar esperando e aí, graças a Deus, nesse período, no final desses três anos, eu já estava me sentindo bem melhor". 
Durante esse período de três anos, o casal realizou alguns procedimentos médicos na tentativa de conseguir engravidar, como induções de ovulação e ultrassons seriados, ${ }^{2}$ bem como a realização de alguns exames na tentativa de identificar a causa da suposta infertilidade. Como os resultados desses exames não identificaram qualquer alteração, Eduarda concluiu que só bastava esperar e orar a Deus para conseguir engravidar. Assim, em uma ocasião em que estava na igreja, teve uma experiência de cura ou intervenção espiritual, na qual o seu ventre foi "tocado por um anjo". Quinze dias depois recebeu o resultado positivo para uma nova gravidez. Apesar da expectativa de que a gestação seria bem-sucedida - devido à experiência de intervenção divina -, um novo aborto espontâneo voltou a acontecer após algumas semanas.

Pouco tempo depois, Eduarda engravidou novamente. Porém, em algumas semanas um novo aborto espontâneo voltou a ocorrer. Nesse momento, então, o médico ginecologista que a acompanhava indicou-lhe um médico especialista no tratamento de casais com diagnóstico de abortamento de repetição. Eduarda e o esposo, assim, buscaram esse médico, realizando todos os muitos exames por ele solicitados. Através desses exames, houve a identificação de algumas alterações Autoimunes ${ }^{3}$ e Aloimunes, ${ }^{4}$ bem como a prescrição e a realização de um tratamento,

2 O ultrassom seriado refere-se ao exame da ultrassonografia realizada em série, isto é, repetidas vezes com o intuito de acompanhar e identificar o momento em que a ovulação vai ocorrer para o coito programado.

3 Fatores Autoimunes: referem-se à "falha em uma parte do sistema imunológico, chamada autotolerância, que resulta em respostas imunes contra as células e tecidos do próprio organismo, geralmente através de produção de autoanticorpos" - que podem prejudicar a implantação embrionária. (Cavalcante \& Barini, 2009, p. 13)

4 Fatores Aloimunes: referem-se aos mecanismos responsáveis pela aceitação ou rejeição entre os indivíduos - ou parte deles - em interação. No caso de uma gravidez normal, assim, o embrião envia mensagens ao sistema imune da mulher, alertando que está ocorrendo uma implantação. Quando as células do sistema imune materno, presentes na cavidade do útero (endométrio) recebem esse sinal, elas promovem uma resposta protetora, estabelecendo um ambiente favorável ao desenvolvimento do concepto. Para alguns casais, porém, a resposta imunológica de aceitação do concepto não ocorre desta forma. O embrião não consegue enviar, adequadamente, a mensagem ao sistema imune materno. As células de defesa localizadas no endométrio reconhecem o embrião como um ser estranho e 
porém, sem sucesso. Isto porque, mesmo após a intervenção médica, Eduarda voltou a experienciar mais outros dois abortos espontâneos.

Os procedimentos médicos após os abortos consistiram em um dos momentos mais difíceis para Eduarda. E foram muitas as razões apontadas por ela: a experiência de dor física como resultado da indução medicamentosa da expulsão dos restos fetais; a percepção de ameaça à sua integridade física pelo uso de anestesia geral; o sofrimento emocional experienciado por ela e por sua família em decorrência da perda e a frustração da rede social ao receber a notícia da interrupção prematura da gestação:

É muito complicado, porque... a gente tem que tomar aqueles remédios,... aí ter que ficar esperando as contrações, 'né, o período certo do remédio agir, abrir o colo do útero, 'né', então, é muito dolorido. Aí o meu esposo trabalha de turno e aí paga um preço alto pra estar ali comigo, entendeu, me acompanhando, minha familia sofre, eu sofro, 'né', ai tem que entrar pra sala de cirurgia, tomar aquela anestesia geral, então isso é tudo muito complicado, muito dolorido. E aí... você voltar, dizer pra todo mundo: 'Ah, perdi',... aí se afasta do trabalho, fica em casa, então assim, tudo é muito chato, aí tudo volta, tudo, o sonho acaba,... aí de repente tudo acaba, então isso é muito dolorido, isso dói muito.

Eduarda relata possuir uma ampla rede de apoio social, incluindo o esposo, vários membros da família extensiva - como mãe, pai, irmã, cunhado -, além de amigos e irmãos da igreja, que lhe ofereceram um suporte emocional percebido como adequado, ao longo de toda a sua trajetória reprodutiva. Isto porque houve o reconhecimento da perda experienciada, bem como a legitimação do seu sofrimento em decorrência destas:

...A presença deles, nunca me deixaram só, em momento algum, enchem a minha casa, e aí conversam, me dão colo, respeitam o meu momento, entendeu, não tem essa coisa de dizer: 'Ah, não chora, Deus vai te dar outro', não, não ouço nada disso, eles respeitam o meu momento de dor, entendeu, choram junto comigo, tanto que as vezes que eu fico no Jorge Valente, quando a familia chega

inicia uma resposta de destruição, não permitindo a invasão uterina, sendo um ambiente desfavorável ao desenvolvimento do concepto. (Cavalcante \& Barini, 2009) 
pra me ver, os médicos ficam às vezes até assustados, aquele batalhão de gente na clínica para me ver [relata esse episódio com uma entonação de alegria], mas eu gosto assim, eu prefiro assim, se eu ficasse só teria sido muito pior.

Assim, após a vivência de seis abortos espontâneos, Eduarda volta a engravidar novamente, tendo sido este o momento em que a entrevista foi realizada. No momento da confirmação da gravidez, a antecipação da possibilidade de estar novamente grávida (orientação para o futuro) a remeteu à sua história prévia de abortamentos (memórias, passado), fazendo emergir sentimentos altamente ambivalentes entre o querer e o não querer estar grávida naquele momento:

Eu 'tava' muito mal, 'tava' muito mal, chorava ...chorava e chorava e chorava com medo de confirmar a gravidez, e ficar com os mesmos medos, 'né', as mesmas preocupações, a ultrassom, não sei o que... Na verdade era um querer a gravidez e na verdade um querer prorrogar, 'né', aquele momento, entendeu, é como se eu não me sentisse ainda preparada pra estar grávida de novo... Eu acho que sentimentalmente, emocionalmente eu acho que eu ainda não tava preparada pra engravidar de novo.

Além dos sentimentos ambivalentes em relação à gravidez, que foi confirmada naquele momento, outro evento contingencial ocorrido no mesmo dia - a perda de uma pessoa significativa (sua avó paterna) - representaria mais uma ruptura em seus planos relacionados à maternidade. Afinal, a avó consistia em uma das pessoas da sua rede familiar/ afetiva que nutria expectativas em relação a esse filho. Eduarda relata que pedia a Deus, através das suas orações, para que sua avó pudesse ver o nascimento do seu filho. Porém, não houve tempo nem mesmo para lhe dar a notícia da gravidez:

A minha avó era uma pessoa que esperava muito..., ela sempre dizia: 'Oh, minha filha, será que vai dar tempo de eu ver o seu neném?', falava: 'Será que vai dar tempo, eu queria tanto ver esse bebê?' e eu orava, pedia muito a Deus que guardasse a vida dela, pra que desse tempo, e toda vez que eu engravidava ela se alegrava, toda vez que eu perdia, ela sofria junto com a gente, entendeu, e aí quando eu vi que eu tinha acabado de descobrir que eu 'tava' grávida e ela tinha acabado de falecer, não deu nem tempo, 'né', de conversar com ela... 
Apesar deste momento difícil, Eduarda relata ter tentado conter-se emocionalmente, bem como cuidar-se fisicamente - como alimentar-se bem e descansar - a fim de não prejudicar a gestação em desenvolvimento. E, apesar do intenso medo de que um aborto ocorra novamente, relata estar tentando não antecipar o futuro, mas viver o momento presente: "a alegria de estar grávida hoje, sem me preocupar com o amanhã". Para esta gestação, outros tratamentos foram sugeridos ao casal pelo médico especialista, como o uso de imunoglobulina humana endovenosa ${ }^{5}$ - um tratamento que possui um elevado custo, mas que está sendo pleiteado pelo casal na Fundação de Hematologia da Bahia (Hemoba).

\section{Mediação semiótica: estratégias para construção de continuidade}

A trajetória reprodutiva de Eduarda, marcada pela recorrência de abortos espontâneos, revela a experiência de importantes rupturas que ameaçam o seu senso de continuidade. Isto é, ameaçam seu senso de identidade (acerca de quem ela era, quem ela é, e o que ela será), exigindo esforços a fim de forjar um senso de continuidade através das transições, bem como construir um senso de integridade ou consistência entre seus valores e ações ao longo do tempo. (Zittoun \& Grossen, 2012) A disrupção no sentido do self demanda, assim, novos movimentos subjetivos de reconstrução do si mesmo.

Com o propósito de entender os mecanismos de reconfiguração do sistema do self-acionados nos momentos subsequentes à ruptura no fluxo da experiência -, foi realizada uma análise dos processos de emergência e mediação semiótica que ocorreram no espaço imaginário do self e foram expressos, de algum modo, através da sua narrativa autobiográfica.

5 Imunoglobulina Humana Intravenosa: é um tratamento indicado para pacientes com hiperatividade das células de defesa do endométrio (denominadas células Natural KillerNK ) e história de abortos repetidos. Consiste em um hemoderivado preparado a partir de sangue de vários doadores. Um fator limitante em seu uso é o custo elevado. (Cavalcante \& Barini, 2009) 
No processo de emergência e mediação semiótica, as pessoas criam e usam signos como um esforço para se relacionar ativamente com o mundo, isto é, para estar preparado para o que está para acontecer ou fazer acontecer. Em cada representação por um signo há uma apresentação, uma sugestão para o futuro - havendo, assim, a construção de uma ponte entre passado e presente para um sentido de futuro possível. Deste modo, em um contexto de incertezas, as pessoas criam signos a fim de construir estabilidade, processo sempre necessariamente dinâmico. (Abbey \& Valsiner, 2004; Valsiner, 2005, 2012)

Deste modo, ao longo da sua trajetória reprodutiva, Eduarda buscou construir signos relativamente estáveis que reduzissem o alto nível de ambivalência desencadeado pela experiência de abortos espontâneos com o propósito de produzir alguma coesão, alguma estabilidade em seu self complexo. Assim, a partir da experiência do primeiro aborto, Eduarda se apropria do signo "cisto" oferecido pelo âmbito médico, como uma possível causa para a ocorrência da perda. No entanto, a fragilidade desse signo tornou-se evidente diante da ambivalência experienciada na sua segunda gestação, na qual seus sentimentos oscilaram entre a alegria e o medo. A ocorrência de um segundo aborto, deste modo, veio confirmar a insustentabilidade desse signo frágil. (Abbey \& Valsiner, 2004) É possível, então, que os elevados níveis de ambivalência e tensão subsequentes a esse evento tenham implicado no que foi percebido por Eduarda como uma "demora" para engravidar novamente. Esta percepção a conduziu a coconstruir com outros significativos alguns significados que explicassem essa "demora". Um desses significados consistiu no nível aumentado de ansiedade, o que a orientou a mudar alguns comportamentos (por exemplo, tentar mudar o foco da sua atenção da maternidade para a vida profissional, a fim de reduzir a ansiedade).

Após três anos sem conseguir engravidar, Eduarda foi surpreendida por uma experiência significativa na sua trajetória, que consistiu no evento de cura ou intervenção divina. Nesta, uma irmã da igreja relata ter visto um anjo tocando o seu ventre. A partir desse evento, a ambivalência pôde ser reduzida, ampliando a expectativa de uma gestação bem-sucedida - futuro subjetivamente antecipado em decorrência do processo de 
mediação semiótica. Em outras palavras, a experiência religiosa de cura possibilitou a construção de dispositivos semióticos que, embora imprecisos, atenderam à tarefa de reduzir a incerteza que Eduarda enfrentava na situação presente. Quinze dias depois dessa experiência, Eduarda soube que estava grávida. Porém, o signo construído a partir da imagem de um "anjo tocando o seu ventre" foi fortemente abalado pela ocorrência de mais um aborto espontâneo. O questionamento do signo, entretanto, ocorreu apenas no nível do significado. O autodiálogo de Eduarda ilustra a decadência do significado atribuído ao signo construído e a ampliação do nível de ambivalência: "eu não entendi, eu disse: 'Meu Deus, a irmã viu um anjo tocar o meu ventre, a gravidez confirmou depois de quinze dias... por que meu Deus?', aí fiquei sem entender". A fim de integrar essa experiência disruptiva e minimizar o nível de ambivalência, Eduarda reforçou o signo atribuindo-lhe ou dando ênfase a outro significado. Ou seja, em vez de o signo da imagem do anjo tocando o seu ventre estar relacionado à superação dos abortos espontâneos, ele foi relacionado à superação da dificuldade para engravidar. Em outras palavras, a experiência de intervenção divina resultou no fim de uma suposta condição de infertilidade: "mas aí eu vi que depois dessa ocasião eu não parei mais de engravidar... graças a Deus a gente não teve mais dificuldade de engravidar”. Conforme afirma Valsiner (2012), o grande poder da linguagem humana, ao guiar a construção de significados, está exatamente na imprecisão desses significados que são construídos pelas pessoas em situações incertas, ampliando as possibilidades de assegurar coerência, reduzir incerteza e garantir continuidade ao longo das trajetórias de desenvolvimento.

Outra experiência significativa em sua trajetória reprodutiva consistiu na realização de um tratamento médico especializado em aborto de repetição. A realização dos muitos exames consistiu em um período difícil para Eduarda, por seu elevado custo, mas, ao mesmo tempo, na oportunidade de identificar, nomear os possíveis fatores relacionados aos abortos de repetição e, com efeito, realizar algum tratamento para impedir novas perdas. A possibilidade de nomear uma experiência afetiva distancia a pessoa daquela experiência, capacitando o self para agir sobre si mesmo e sobre a situação (Gillespie, 2007): 
Se não tinha uma explicação pra nossa situação, então eu acho que toda a possibilidade tem que ser estudada, tem que ser avaliada, entendeu. E aí quando eu e o meu esposo viemos aqui, a gente, 'né', 'ficamos' felizes com o Dr. M. porque ele tapa todas as brechas, assim, todas as possibilidades que podem levar você a perder um bebê... a gente está... no mesmo objetivo, na mesma intenção, que é realmente cuidar de tudo, tapar todas as brechas que a gente puder, pra não perder de novo.

O campo médico, assim, forneceu-lhe alguns signos relacionados aos abortos espontâneos, que consistiram em alterações autoimunes e aloimunes. A partir disso, o casal deu início ao tratamento denominado Imunização com Linfócitos Paternos. ${ }^{6}$ Apesar do tratamento realizado, Eduarda voltou a sofrer outros dois abortos espontâneos, aumentando novamente o nível da ambivalência experienciada: "só que aí, mesmo depois do tratamento, eu perdi... o quinto bebê, foi a quinta gravidez, com tratamento direitinho, fizemos a vacina, tomávamos o remédio direitinho, e aí a gente ficou sem entender". Mais uma vez, o questionamento do signo ocorreu no nível do significado. Assim, com o propósito de minimizar o alto nível de ambivalência suscitado pela ineficácia do tratamento médico, Eduarda relativizou o significado do signo "tratamento médico especializado", construindo o significado de prolongamento da vida do feto: "ele [o feto] chegou até nove semanas, foi o que mais, foi o único que foi até nove semanas, porque o outro foi até sete, oito, ele foi até nove semanas".

Porém, apesar desse movimento de emergência e mediação semióticas - a fim de minimizar as tensões, as ambivalências, mantendo certa estabilidade - outras vozes, de outros significativos, colocaram em questão essa rede frágil de significados construída por Eduarda. Conforme Valsiner (2012), os mundos pessoal-culturais estão constantemente sujeitos à entrada de sugestões sociais heterogêneas, frequentemente con-

6 Imunização com linfócitos paternos: é um tratamento imunológico para casais com abortos recorrentes de causa aloimune (crossmatch negativo). O objetivo do tratamento é preparar o sistema imune materno para reconhecer o embrião no momento da nidação. Para isso, são realizadas imunizações intradérmicas preparadas a partir de sangue do parceiro. (Cavalcante \& Barini, 2009) 
traditórias ou ambivalentes. Nesse sentido, o esposo expressa ideias de desistência em relação a dar continuidade à tentativa de terem um filho, que é entendida por Eduarda como um "problema" dele: "eu acho que eu consigo superar melhor do que ele, porque ele já teve assim ideias de desistência, entendeu, pensamentos negativos em relação a toda essa nossa luta, toda essa busca, eu graças a Deus nunca tive esse problema, não".

Além disso, outras pessoas vêm questionando a eficácia do tratamento médico realizado, na medida em que apesar do tratamento outros abortos espontâneos ocorreram. Deste modo, essas vozes apontam para determinadas incongruências, para a fragilidade dos signos construídos. E isto gerou certo incômodo para Eduarda, suscitando nova ampliação da ambivalência. Diante dessas tensões, Eduarda recorreu a algumas estratégias semióticas e dialógicas a fim de minimizar as ambivalências que elas provocavam: primeiro, essas vozes foram desqualificadas no interior do self: "[essas pessoas] são coleguinhas sem muita intimidade, pessoas que eu não tenho muita intimidade, mas que 'tão' perto de mim...". Logo em seguida, planejou através do diálogo ocorrido no interior do self, uma ação futura com o intuito de silenciá-las, desqualificando o conteúdo expresso por essas vozes: "eu falei assim, eu vou me posicionar melhor em relação a essas pessoas, não vou permitir que elas fiquem falando, que elas fiquem especulando isso não, entendeu? Que conhecimento tem pra ficar falando sobre as coisas?".

Um dos questionamentos realizados por esses outros consistiu em: por que não descontinuar o tratamento médico, que já se mostrou ineficaz, e confiar unicamente na providência divina? A partir dessa indagação, Eduarda realizou o movimento de tentar conciliar esses dois campos de signos hipergeneralizados (Valsiner, 2012) que, muitas vezes, operam em lados opostos. Esforçou-se, assim, por encontrar uma articulação entre as várias "esferas da experiência" (Zittoun \& Grossen, 2012), em realizar um processo de síntese pessoal-cultural com o propósito de manutenção do senso de continuidade do self:

Eu penso assim, Deus é que deu sabedoria ao homem, ele que criou a ciência, entendeu, infelizmente é a gente que usa a ciência pro lado negativo, 'né', faz dela 
pra fazer coisas que acaba destruindo a si próprio, entendeu, mas, assim, se ela é bem usada, a fé e a ciência podem andar juntas muito bem, sem uma agredir a outra, entendeu, porque tudo vem de Deus, tudo foi Deus que criou [fala de modo enfático esse trecho].

O mesmo movimento de síntese semiótica entre as esferas religiosa e médica é realizado na construção de significados acerca da etiologia dos abortos de repetição.

Eu acredito nesses exames que o Dr. M. fez, da prova cruzada,... que é o crossmatch... Eu acho que... seja isso mesmo essa questão dos fatores, 'né', auto e aloimune... Mas, espiritualmente falando, eu penso que seja permissão de Deus mesmo, que tem o tempo certo pra acontecer.

Assim, Eduarda segue negociando sua orientação para determinadas dimensões da experiência futura, em processos contínuos de posicionamento e reposicionamento diante do Outro.

\section{As dinâmicas no âmbito do self: processos dialógicos envolvidos na autorregulação semiótica}

No espaço imaginário do self, duas posições do Eu se destacaram ao longo da trajetória reprodutiva de Eduarda, compondo um campo que envolveu a construção de hierarquias: a posição dominante Eu-religiosa (em seu diálogo constante com Deus) e a posição relevante, porém subordinada à primeira, Eu-paciente (em diálogo com o médico especialista). Ambas dão sustentação à outra posição do Eu central no sistema do self: o Eu-mãe.

Vale ressaltar que apesar da existência de algumas tensões na relação com outros significativos, como descrito anteriormente, muitas foram as forças favoráveis à persistência de Eduarda em tornar-se mãe. Afinal, ela encontrou reconhecimento e suporte em outros sociais culturalmente valorizados, na esfera religiosa e médica bem como na esfera familiar. Essas sugestões sociais, deste modo, atuaram empoderando a posição Eu-mãe (potencialmente futura), fragilizada pela experiência de abortos 
recorrentes. Promoveram, além disso, certa coalizão interna de posições do Eu (internas e externas) em torno dessa outra posição do Eu relevante, o Eu-mãe, regulando, assim, sua conduta nessa direção.

Apesar disso, a possibilidade de não conseguir ter um filho é imaginada por Eduarda, através de um posicionamento subjetivo do tipo "como se" (as if) - que pode ser expresso em termos de um questionamento: "e se eu não tiver um filho?". Tal posicionamento a orienta em direção ao futuro, funcionando como um organizador semiótico de ações futuras, sendo associado à experiência inevitável da morte, a qual só lhe resta aceitação:

Eu penso assim,... se não vai acontecer, se a gente não vai ter o bebê... pra mim eu não tenho que tomar decisão drástica nenhuma na minha vida, entendeu, eu tenho que aceitar [ênfase], eu tenho que aprender a viver, 'né', a realidade, entendeu, tenho que aprender a superar, a gente tem que ser flexível,... não adianta lutar contra uma realidade, entendeu, é que nem a morte, não adianta você não querer aceitar, você só vai sofrer mais ainda, então é melhor aceitar que ela existe e que a dor vai passar e que você vai aprender a viver com a falta daquela pessoa, entendeu?

Apesar de essa possibilidade ter sido aventada por Eduarda, a posição do Eu-mãe permanece como uma posição central em seu sistema de self. Isto porque, ela constrói a possibilidade da maternidade a partir da adoção de uma criança. E nesse sentido, Eduarda cria uma aliança entre a posição do Eu-mãe adotiva (potencialmente futura) com outra posição do Eu altamente relevante: o Eu-religiosa. Afinal, ela reflete: e se for da vontade de Deus que eu adote uma criança? (posicionamento subjetivo do tipo "as if"). Nesse caso, o signo "vontade de Deus" consiste em um signo promotor, um significado hipergeneralizado que promove a integração da ambivalência. (Valsiner, 2012) Além disso, essas posições do $\mathrm{Eu}$, centrais e dominantes no sistema do self, apresentam-se, então, interligadas - uma reforçando a outra - e carregadas de afeto, organizando o campo da experiência:

Quando eu penso assim, eu lutando por um filho [chora],... querendo um bebê pra mim, eu lembro daquelas criancinhas que estão lá nas creches, entendeu, lutando por uma mãe, e eu aqui querendo um filho... por que eu não vou lá buscar um pra 
mim, entendeu? E aí eu realizo o desejo do meu coração e o desejo dele?... Eu gostaria de dar um lar pra uma criança que todos os dias pede a Deus por uma familia.

Eis o ponto de bifurcação na trajetória reprodutiva de Eduarda: por que não adotar? Alguns diálogos são, então, estabelecidos entre as posições do Eu internas dominantes (Eu-religiosa, Eu-mãe, Eu-esposa) com outros significativos (posições do Eu externas) (crianças órfãs imaginárias e o esposo). A tensão desse ponto de bifurcação é intensificada com a recusa do marido em aceitar a adoção como um meio de alcançar a paternidade almejada:

Só que infelizmente o meu marido ele não pensa da mesma forma, ele foca só o lado negativo da adoção. Eu sei... que a adoção pode ter seus lados positivos ou negativos, mas eu prefiro valorizar os positivos, porque os negativos você pode viver também com os seus filhos do seu sangue, da sua própria carne, da sua própria familia, como muitos casos que a gente vê aí... Ele pensa que, se ele adotar um filho, hoje ele estaria assinando o atestado dele de derrota, de que desistiu, de que não aguentou esperar... Eu não penso assim, eu adotaria não pra suprir uma falta minha, carência de mãe, mas por amor, por me sentir no lugar daquelas crianças, entendeu, eu hoje que tenho o sentimento de ter um filho e não consigo, penso a dor de querer ter uma mãe, uma familia e não ter, pra mim deve ser bem pior, com certeza bem pior.

É interessante observar que estas experiências ou opções do curso de vida não são meramente pessoais, mas experiências historicamente estruturadas. (Yasuda, 2005) Ou seja, apesar de Eduarda considerar a possibilidade de adotar uma criança, seu esposo e, talvez, outras pessoas da sua rede social, não reconheçam a adoção como um sistema social para ter um filho. Eduarda, porém, através da sua narrativa, parece empenhar-se em tentar legitimar esse caminho alternativo para se tornar mãe, construindo argumentos que possam levar o marido a reconhecer a adoção como um meio legítimo para eles alcançarem a maternidade/ paternidade. Em sua retórica, como no trecho citado acima, faz uso de signos hipergeneralizados, carregados de afeto, como "amor", "dor", "família” - que guiam ações. Além disso, recorre a diálogos com Deus, uma posição do Eu altamente relevante para o sistema do self: 
Peço a Deus, oro a Deus sobre isso, que se de repente é um projeto que Ele tem na nossa vida, que Ele toque no coração de meu marido e flexibilize o coração dele, tire essas ideias negativas, 'né', oriente ele.

Deste modo, o movimento realizado no self dialógico, externalizado através da sua narrativa, tem o propósito principal de manter a posição Eu-mãe - posição central no sistema do self -, apesar da experiência de repetidas perdas, da ineficácia das intervenções médicas e religiosas e das vozes contrárias a esse movimento. Este processo é definido por Valsiner (2002) como autorregulação semiótica, isto é, um processo sistêmico no qual o self mantém a si mesmo enquanto organiza o fluxo sempre novo da experiência pessoal. Para Valsiner, o self dialógico opera como um sistema catalítico, onde os seus próprios componentes (posições do Eu) reproduzem a si mesmos enquanto lidam com a experiência de novidade.

Assim, a posição Eu-mãe adotiva configura-se como uma síntese de uma nova posição do $\mathrm{Eu}$ - projetada para o futuro. Contendo não só novidade, mas também a manutenção relativa da posição do Eu-mãe "original”, que é constantemente ameaçada no fluxo da experiência. Além disso, essas posições do Eu, que se confundem e até certo ponto se integram em uma só, são alicerçadas por outra posição do Eu altamente relevante e dominante no sistema do self de Eduarda: o Eu-religiosa. Posição do Eu não só dominante sobre as outras em um determinado momento, mas que estabelece uma gama de expectativas para o futuro. Afinal, ao longo de toda a narrativa, é a voz dessa posição do Eu a principal autora. Posição que cria alguma ordem e direção na multiplicidade de posições do self-organizando, inovando e desenvolvendo o self ao longo do tempo (posição promotora). É através dela que a sua história passada de abortos repetidos é ressignificada e que o futuro é subjetivamente antecipado, através do estabelecimento de uma gama de expectativas em termos do que poderia acontecer num próximo momento - em articulação com a posição Eu-paciente (esfera médica). Assim, o nível de incerteza pôde ser reduzido, na medida em que a direção é concedida a uma posição poderosa e importante, autorizada a dominar o self como um todo. (Hermans \& Hermans-Konopka, 2010) 
Nesse sentido e com o propósito de dar sustentação ao Eu-religiosa, Eduarda faz uso de um importante recurso simbólico - um mediador do seu próprio pensamento e funcionamento psicológico (Zittoun \& Grossen, 2012) -, a Bíblia. Através desse recurso, Eduarda consegue refletir e dar sentido à sua história de abortos recorrentes, bem como a si mesma perante os outros sociais. Afinal, relata que a partir da sua história pessoal aprendeu a "confiar em Deus como um pai, que cuida dos seus filhos", identificando-se com os personagens bíblicos e o sofrimento experienciado por eles:

Acho que senti na pele coisas que pessoas da Bíblia sentiram, sofreram... Como a gente conhece várias histórias na Bíblia, tem coisas realmente ruins que precisam acontecer na nossa vida, não pra gente sofrer, se martirizar, mas pra gente crescer, pra gente aprender, pra Deus também abençoar outras vidas que possam, 'né', vir a passar pelo mesmo problema, ou até evitar que elas passem pelo mesmo problema, que não é todo mundo que suportaria, entendeu, ter esse número, 'né', tantas perdas.

No trecho acima, podemos notar a influência da religião na construção cultural-pessoal do sofrimento como redenção, fazendo-o funcionar voltado para metas sociais e pessoais específicas: "pra gente crescer, pra gente aprender...". Deste modo, essa ênfase sobre o sofrimento enquanto redenção guia a pessoa para agir e, através dessa ação, para aceitar uma determinada filosofia de vida. (Valsiner, 2012) Assim, ao identificar-se com os personagens da Bíblia, Eduarda empodera o seu próprio self na medida em que se apropria do valor moral e espiritual, e da força emocional desses personagens do domínio externo para o domínio interno (Eu-personagem bíblico), atribuindo-se um status de modelo, isto é, da sua história servindo como exemplo para outras mulheres, ativando um poderoso campo afetivo. Deste modo, Eduarda constrói algum significado para o sofrimento advindo da experiência de abortos repetidos, ao mesmo tempo em que dá sustentação à importante posição Eu-religiosa, que ganha uma nova síntese, sendo reconfigurada em uma nova posição do Eu, isto é, Eu-filha de Deus. Posição do Eu que, por sua vez, alicerça o Eu-mãe. Afinal, a experiência de incerteza em decorrência da trajetória 
reprodutiva marcada por abortos espontâneos - e a inevitável sensação de perda de controle sobre a própria vida - pode ser minimizada através dessas relações dialógicas estabelecidas com Deus. Ou seja, Deus está no controle da vida das pessoas, tem o poder necessário para isto (crença da posição Eu-religiosa); a sua história de perdas gestacionais tem algum sentido, algum significado mais profundo, de nível espiritual (crença da posição Eu-personagem bíblico); e o desfecho dessa história deve ser positiva, afinal, Deus é um pai que cuida dos seus filhos (crença posição Eu-filha de Deus). O cuidar também configura-se como um signo hipergeneralizado.

Eduarda, então, faz uso de uma série de recursos simbólicos em seu fluxo de pensamento, para resolver suas questões internas. O mais importante entre esses vem da religião. Ao evocar "Deus" em suas reflexões, há a criação de um campo afetivo hipergeneralizado de espiritualidade. Nesse sentido, a sua luta para ter um filho (que assume o significado de martírio, tal como Cristo na cruz) é profundamente pessoal, apesar de ela utilizar os significados sociais da sua comunidade (símbolos religiosos) para expressar e resolver questões internas. (Wagoner, Gillespie, Valsiner, Zittoun, Salgado, \& Simão, 2011)

Assim, a apresentação da experiência passada (abortos espontâneos repetidos, apesar da intervenção divina e médica) parece operar como um catalisador para a construção de novas posições do Eu dentro de uma gama de possibilidades (Ex: Eu-mãe adotiva, Eu-filha de Deus). Considerando-se o momento da construção da sua autobiografia como um dos pontos de começo para a construção de significados pessoais. Ponto de começo para uma construção reflexiva denominado por Valsiner (2002) como o SISTEMA-EU-AQUI-AGORA (HERE-NOW-I-SYSTEM, HNIS) - uma unidade mínima do espaço (aqui), tempo (agora) e agente (Eu). A partir do HNIS, há o estabelecimento de posições do Eu aceitáveis para o futuro imediato, baseado sobre as experiências passadas (Valsiner, 2002). Isto porque o ato de narrar dá coesão à diversidade das suas experiências, promovendo a conexão entre eventos passados, presentes e futuros (ver Figura 11). A narrativa, segundo Gillespie (2007), é a consciência do self no tempo. 


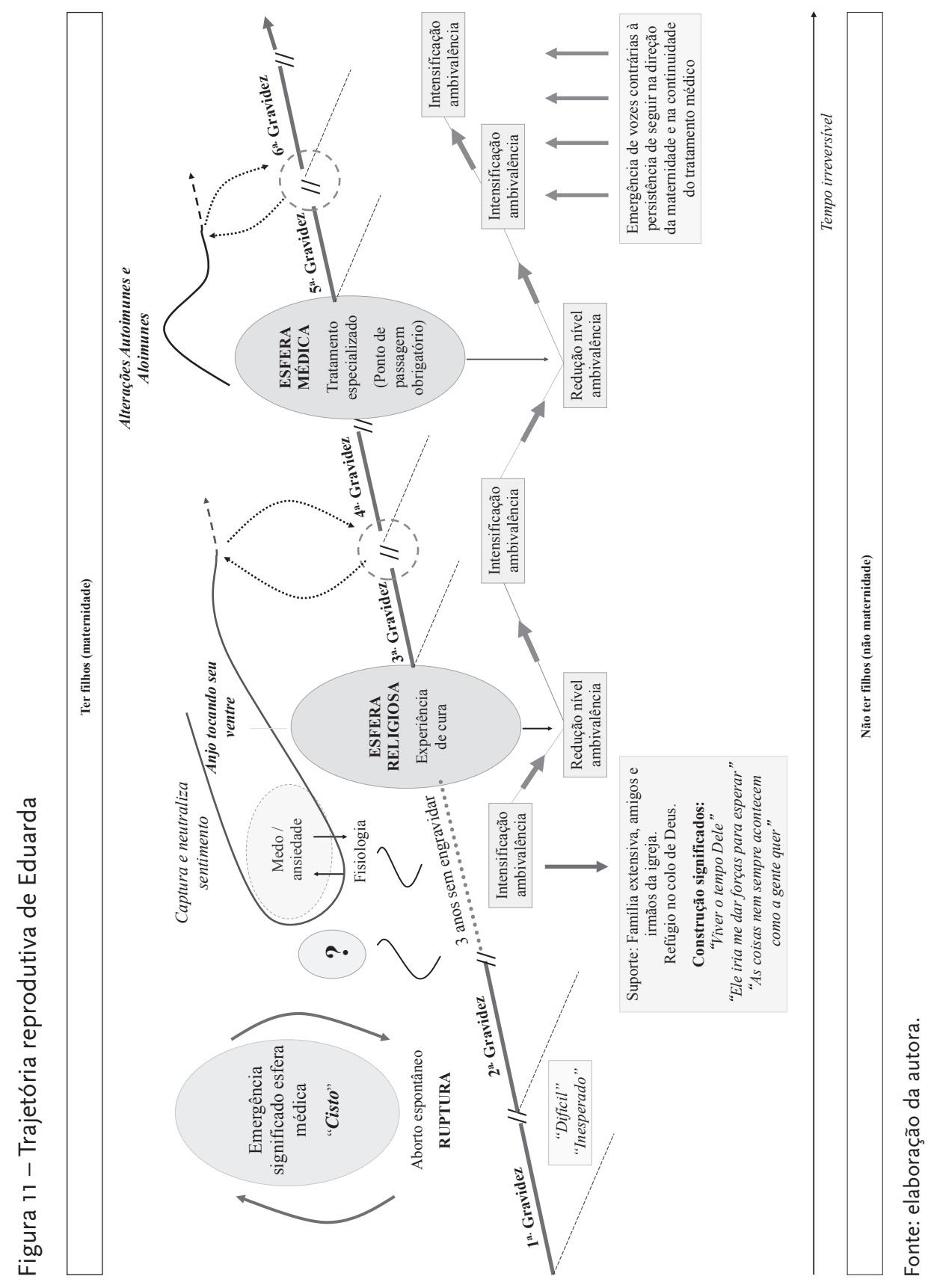




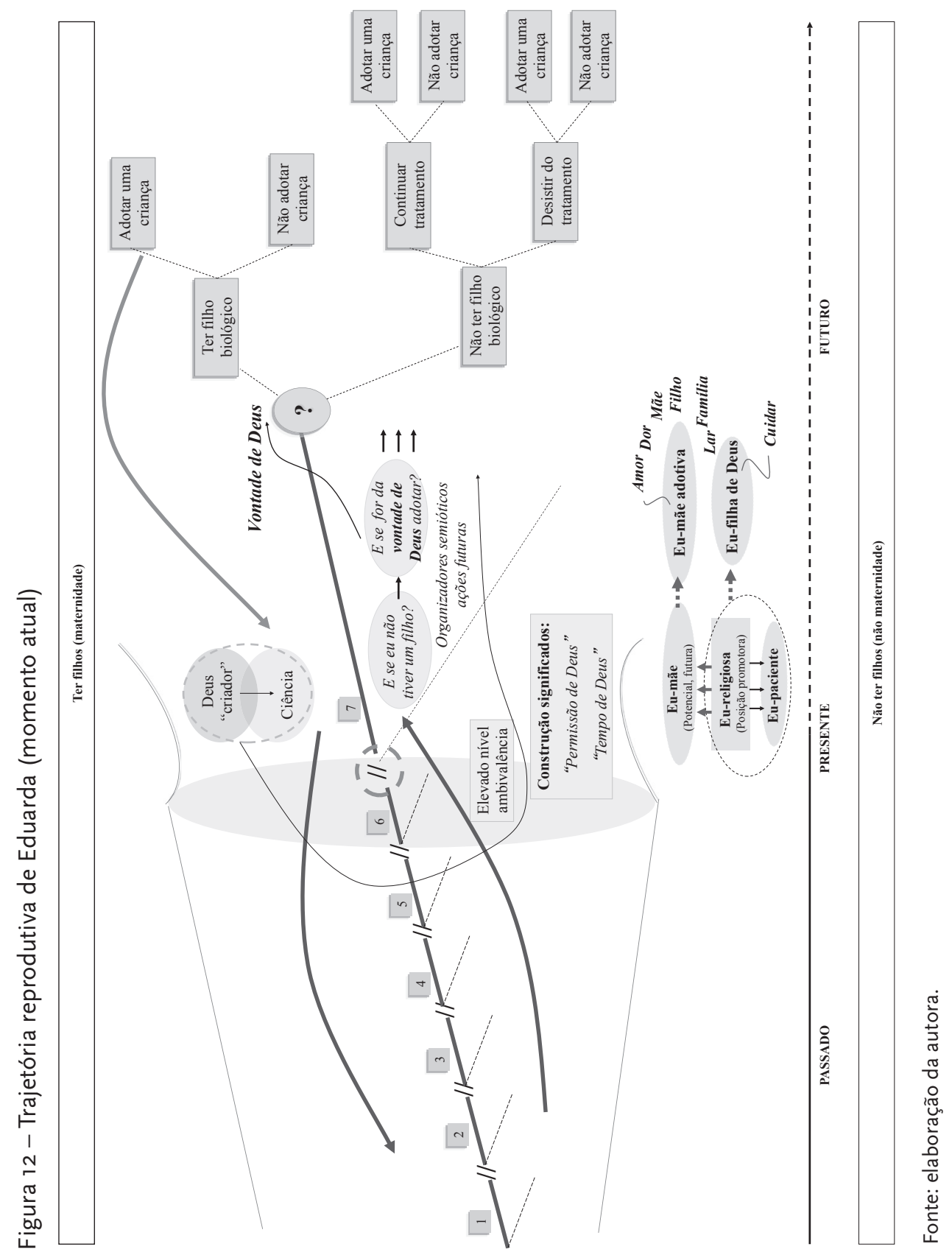




\section{Tempo de concluir}

O relato autobiográfico de Eduarda acerca da sua trajetória reprodutiva marcada por abortos espontâneos recorrentes revela que a construção e reconstrução do self envolvem complexas articulações no tempo irreversível, onde o passado e o futuro orientam novas posições no tempo presente. O Modelo de Equifinalidade de Trajetórias, assim, permite considerar todas essas dimensões no âmbito do sistema do self em desenvolvimento. Ou seja, contempla a dinâmica do movimento da pessoa no tempo irreversível em direção ao futuro.

Considerando a questão do tempo, pode-se refletir sobre a dimensão da ruptura e da inevitável construção de significado no que tange à ocorrência de cada um dos abortos espontâneos. Assim, pode-se dizer que a experiência do primeiro aborto espontâneo implicou em descontinuidades em relação às expectativas e planos mais imediatos (momento presente/futuro próximo), isto é, de ter aquele bebê, de vivenciar a maternidade naquele momento, conforme havia sido planejada pelo casal. Nesse sentido, é possível que a posição “Eu-mãe" - potencialmente futura e altamente relevante para o sistema do self - não seja ainda percebida como realmente ameaçada, mas apenas temporariamente adiada. Deste modo, não há necessariamente a confrontação com uma redefinição da identidade - que inclua a possibilidade desse Eu-mãe não se realizar ou, pelo menos, não se realizar conforme planejado (de um filho biológico).

Porém, a repetição das perdas gestacionais torna essa reflexão necessária, isto é, a mulher pode vir a não se tornar mãe. E isto consiste em uma ruptura mais profunda e de longo prazo, que afeta a perspectiva de futuro dessa mulher, bem como exige a reconstrução de planos e metas passadas, levando a redefinições da identidade. Isto porque a concretização dessa possibilidade mudaria radical e profundamente o que Eduarda e os outros imaginavam para ela. O futuro, marcado por essa possibilidade, é antecipado, interferindo em como ela percebe a si mesma e o modo como age. 
Assim, o caso de Eduarda ilustra a tentativa exaustiva de sustentar a viabilidade da posição do Eu-mãe, ainda que em uma versão reformulada de "Eu-mãe adotiva". Ou seja, uma tentativa de sustentar certa estabilidade (que se relaciona com a questão da identidade). E assim, evitar uma mudança mais profunda em sua identidade, uma ruptura definitiva daquilo que ela e os outros imaginavam que poderia ser, vir a ser.

Por fim, é preciso considerar ainda que a maternidade configura-se como um signo hipergeneralizado, que permeia e promove o modo de pensar e sentir em sua totalidade - à medida que se atravessa a miríade de espaços da vida cotidiana. Uma noção cultural carregada de valor que sobredetermina as mentes humanas - sendo socialmente promovida e pessoalmente internalizada. Um signo que atua como um mediador semiótico nos processos de comunicação humana, tanto entre pessoas e instituições, como na condição de regulador intrapsicológico. Deste modo, o poder dessa noção cultural e seu significado hipergeneralizado orientam a conduta humana, bem como as necessidades afetivas. (Valsiner, 2012) 